\title{
Erratum to: Moving from medical to health systems classifications of deaths: extending verbal autopsy to collect information on the circumstances of mortality
}

Lucia D'Ambruoso ${ }^{1,2,3^{*}}$, Kathleen Kahn ${ }^{2,3,5}$, Ryan G. Wagner ${ }^{2,3}$, Rhian Twine ${ }^{3}$, Barry Spies ${ }^{4}$, Maria van der Merwe ${ }^{4}$, F. Xavier Gómez-Olivé, ${ }^{3,5}$, Stephen Tollman ${ }^{2,3,5}$ and Peter Byass ${ }^{1,2,3}$

\section{Erratum}

After publication of the original article [1] it was brought to our attention that a couple of typos were incorporated into the published text. Please note that the third author name was incorrectly written as 'Ryan G. Wager'. The correct author name should be 'Ryan G. Wagner'.

Secondly, there was a repetition of the word 'deaths' in the first sentence of the results paragraph.

These have both now been corrected on the BioMed Central website.

\begin{abstract}
Author details
'Institute of Applied Health Sciences, University of Aberdeen, Scotland, UK. ${ }^{2}$ Umeå Centre for Global Health Research, Umeå University, Umeå, Sweden. ${ }^{3}$ MRC/Wits Rural Public Health and Health Transitions Research Unit, School of Public Health, Faculty of Health Sciences, University of the Witwatersrand, Johannesburg, South Africa. ${ }^{4}$ Directorate for Maternal, Child, Women and Youth Health and Nutrition, Mpumalanga Department of Health, Nelspruit, Mpumalanga, South Africa. ${ }^{5}$ INDEPTH: An International Network for the Demographic Evaluation of Populations and Their Health, Accra, Ghana.
\end{abstract}

Received: 11 July 2016 Accepted: 11 July 2016

Published online: 19 July 2016

\section{References}

1. D'Ambruoso, et al. Moving from medical to health systems classifications of deaths: extending verbal autopsy to collect information on the circumstances of mortality. Global Health Research and Policy. 2016;1:2.

\footnotetext{
* Correspondence: lucia.dambruoso@abdn.ac.uk

${ }^{1}$ Institute of Applied Health Sciences, University of Aberdeen, Scotland, UK

2Umeå Centre for Global Health Research, Umeå University, Umeå, Sweden

Full list of author information is available at the end of the article
}

\footnotetext{
Submit your next manuscript to BioMed Central and we will help you at every step:

- We accept pre-submission inquiries

- Our selector tool helps you to find the most relevant journal

- We provide round the clock customer support

- Convenient online submission

- Thorough peer review

- Inclusion in PubMed and all major indexing services

- Maximum visibility for your research
}

Submit your manuscript at www.biomedcentral.com/submit 